\title{
Reply to the Letter to the Editor “The Microbiota in Parkinson's Disease: Ranking the Risk of Heart Disease"
}

\author{
Masaaki Hirayama $^{a} \quad$ Kinji Ohno ${ }^{b}$ \\ aDepartment of Pathophysiological Laboratory Sciences, Nagoya University Graduate School of Medicine, Nagoya,

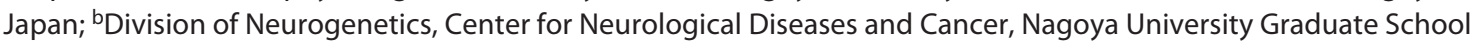 \\ of Medicine, Nagoya, Japan
}

\section{Dear Editor,}

Thank you for sharing an interesting thought with us. Dr. Scorza and colleagues state that changes in gut microbiota may also affect the cardiac functions in patients with Parkinson's disease (PD). Especially, they suggest that sudden death in PD may be associated with alterations in gut microbiota. They recently wrote a review article on cardiac abnormalities in PD [1]. They concluded that cardiac autonomic dysfunction is the most prominent feature in the heart in PD. We indeed reported the impairment of cardiac sympathetic nerves in PD using MIBG myocardial scintigraphy first in the world [2]. In addition, we reported that sympathetic nerves in peripheral blood vessels throughout the body are impaired in PD patients with severe orthostatic hypotension [3]. In PD, the cardiac sympathetic nervous system is overreacted to sympathomimetic drugs [4], and the circulatory response to exercise is impaired [5], indicating that the heart in PD exhibits the disruption of homeostasis to external stimuli. Impairment of blood pressure regulation is not limited to orthostatic hypotension. Even in the supine position, the occurrence of postprandial hypotension with fainting can cause trauma and aspiration pneumonia associated with prolonged circulatory failure and loss of conscious-

karger@karger.com www.karger.com/anm

Karger"
(C) 2022 The Author(s)

Published by S. Karger AG, Basel

This article is licensed under the Creative Commons Attribution 4.0 International License (CC BY) (http://www.karger.com/Services/ OpenAccessLicense). Usage, derivative works and distribution are permitted provided that proper credit is given to the author and the original publisher. ness [6]. Furthermore, these autonomic disturbances are associated with hyposmia in early-stage PD [7]. We agree that sudden death in PD can be causally associated with autonomic failure in PD. Autonomic neuropathy can be associated with gut dysbiosis, since animal experiments show that administration of alpha-synuclein to the intestinal tract propagates alpha-synuclein to the heart and sympathetic ganglia [8]. An article cited by Dr. Scorza and colleagues shows that Bacteroides, Enterobacteriace$a e$, and Streptococcus were increased in coronary atherosclerosis. We, however, showed that Bacteroides was rather decreased in PD, and the other taxa were not changed in PD [9]. As introduced by Dr. Scorza and colleagues, trimethylamine is converted from choline and carnitine by gut microbiota, and trimethylamine- $\mathrm{N}$-oxide promotes atherosclerosis [10]. The production of trimethylamine- $\mathrm{N}$-oxide is high in subjects with the Bacteroides type of enterotype [11]. Again, this is different from what we observed in PD. In heart failure, pathogenic bacteria such as Campylobacter, Salmonella, and Enterobacteriaceae are increased in the intestine [12], which is also different from the changes in gut microbiota in PD. As far as we know, gut microbiota in cardiac diseases is different from what we observe in PD. We have not evaluated de- 
tailed cardiac functions except for MIBG scintigraphy in our PD patients, and the association of gut microbiota and cardiac functions in PD remains elusive. We agree that a possibility proposed by Dr. Scorza and colleagues needs to be further analyzed in detail in the future.

\section{Conflict of Interest Statement}

The authors have no conflicts of interest to declare.

\section{Funding Sources}

There was no funding for this reply.

\section{Author Contributions}

Both authors contributed equally.

\section{References}

1 Scorza FA, Fiorini AC, Scorza CA, Finsterer J. Cardiac abnormalities in Parkinson's disease and Parkinsonism. J Clin Neurosci. 2018 Jul; 53:1-5.

2 Hakusui S, Yasuda T, Yanagi T, Tohyama J, Hasegawa Y, Koike Y, et al. A radiological analysis of heart sympathetic functions with meta-[123I]iodobenzylguanidine in neurological patients with autonomic failure. J Auton Nerv Syst. 1994 Sep;49(1):81-4.

3 Hirayama M, Hakusui S, Koike Y, Ito K, Kato $\mathrm{T}$, Ikeda $\mathrm{M}$, et al. A scintigraphical qualitative analysis of peripheral vascular sympathetic function with meta-[123I]iodobenzylguanidine in neurological patients with autonomic failure. J Auton Nerv Syst. 1995 Jun 25;53(23):230-4.

4 Nakamura T, Hirayama M, Ito H, Takamori M, Hamada K, Takeuchi S, et al. Dobutamine stress test unmasks cardiac sympathetic denervation in Parkinson's disease. J Neurol Sci. 2007 Dec 15;263(1-2):133-8.
5 Nakamura T, Hirayama M, Yamashita F, Uchida K, Hama T, Watanabe $\mathrm{H}$, et al. Lowered cardiac sympathetic nerve performance in response to exercise in Parkinson's disease. Mov Disord. 2010 Jul 15;25(9):1183-9.

6 Hirayama M, Watanabe H, Koike Y, Hasegawa Y, Kanaoke Y, Sakurai N, et al. Postprandial hypotension: hemodynamic differences between multiple system atrophy and peripheral autonomic neuropathy. J Auton Nerv Syst. 1993 Apr;43(1):1-6.

7 Mizutani Y, Nakamura T, Okada A, Suzuki J, Watanabe $\mathrm{H}$, Hirayama $\mathrm{M}$, et al. Hyposmia and cardiovascular dysautonomia correlatively appear in early-stage Parkinson's disease. Parkinsonism Relat Disord. 2014 May; 20(5):520-4.
8 Van Den Berge N, Ferreira N, Gram H, Mikkelsen TW, Alstrup AKO, Casadei N, et al. Evidence for bidirectional and trans-synaptic parasympathetic and sympathetic propagation of alpha-synuclein in rats. Acta Neuropathol. 2019 Oct;138(4):535-50.

9 Hirayama M, Ohno K. Parkinson's disease and gut microbiota. Ann Nutr Metab. 2021; 77(Suppl 2):28-35.

10 Tuomisto S, Huhtala H, Martiskainen M, Goebeler S, Lehtimäki T, Karhunen PJ. Agedependent association of gut bacteria with coronary atherosclerosis: Tampere Sudden Death Study. PLoS One. 2019;14(8):e0221345.

11 Wu GD, Chen J, Hoffmann C, Bittinger K, Chen YY, Keilbaugh SA, et al. Linking longterm dietary patterns with gut microbial enterotypes. Science. 2011 Oct 7;334(6052): 105-8.

12 Pasini E, Aquilani R, Testa C, Baiardi P, Angioletti $\mathrm{S}$, Boschi F, et al. Pathogenic gut flora in patients with chronic heart failure. JACC Heart Fail. 2016 Mar;4(3):220-7. 